The Israeli Journal of Aquaculture - Bamidgeh, IJA_72.2020.1167548, 8 pages

CCBY-NC-ND-4.0 • https://doi.org/10.46989/001c.19140

Produced by the AquacultureHub, a non-profit foundation

The IJA is an Open-Access, scientific journal

Sale of IJA articles is strictly forbidden

\title{
Edwardsiellosis in freshwater angelfish (Pterophyllum scalare)
}

\author{
Emre Turgay* \\ Faculty of Aquatic Sciences, Istanbul University \\ Ordu Cad. No:8, 34134 Istanbul, Turkey
}

Keywords: Edwardsiellosis, Edwardsiella tarda, freshwater angelfish, Pterophyllum scalare

\begin{abstract}
The freshwater angelfish (Pterophyllum scalare) with its many varieties is one of the most popular species in the ornamental market. The moribund freshwater angelfish individuals (20-25 g in weight) were sampled from an ornamental fish production facility to determine the cause of mortalities started immediately in fish without any other visible finding except the loss of appetite. The mortality rate in the population was as high as $50 \%$ within a week. Bacteriological samples were taken from internal organs for the identification of the causative agent. Hemorrhage in the eyes, loss of scales and skin depigmentation were the most obvious external finding in the moribund fish. Internally; the liver was pale, the spleen was enlarged and the intestinal walls were thinned. According to conventional biochemical and physiological tests and 16S rRNA gene sequencing, all isolated bacteria were identified as Edwardsiella tarda. The antimicrobial susceptibility test performed using the disk diffusion test showed that the $E$. tarda strains we obtained were sensitive to enrofloxacin, sulfamethoxazole with trimethoprim, furazolidone and flumequine but resistant to ampicillin and tetracycline antibiotics.
\end{abstract}

* Corresponding author. e-mail: eturgay@istanbul.edu.tr 


\section{Introduction}

Historical records on ornamental fish trade reveal that it has a history dating back to ancient times. However, in today's world this trade has become a giant industry with millions of enthusiasts around the world. In ornamental fish trade, marine species are often obtained from wild sources, while freshwater species are produced through aquaculture (Tlusty, 2002). Although detailed statistical studies are not up-to-date and sufficient, according to some calculations, approximately 2 billion live fish are traded worldwide every year. It is stated that the ornamental fish trade, which covers more than a hundred countries, has a trade volume of approximately 15 to 30 billion dollars. While Asian countries led by Singapore are the most important exporters; USA, European Union and Japan are among the biggest importers of the ornamental fish trade (Ladisa et al., 2017; Evers et al., 2019). Moreover, it is observed that a large part of the trade consists of freshwater species obtained through aquaculture, and majority of them is carried out on about 30 species including the freshwater angelfish (Pterophyllum scalare) (Dey, 2016).

Both marine and freshwater ornamental fish production requires the maintenance of hundreds of different species that have different needs biologically, nutritionally and environmentally. In addition, the confined aquarium / tank environment, where more than one fish species is kept together frequently, is a very favorable environment for the spread of diseases. Fish populations kept in such an environment can easily get diseases due to deviations in optimal conditions necessary to maintain their health, and infections can spread quickly and easily among individuals thanks to the nature of the environment (Noga, 2010).

The freshwater angelfish (Pterophyllum scalare), belonging to the family Cichlidae, is a species native to the Amazon basin in Peru, Colombia and Brazil (Ortega and Vari, 1986; Kullander, 2003). With its many varieties in the ornamental market, it is one of the most popular species among tropical aquarium fish due to its special shape, color and behavior. Although so many parasitic, viral, fungal and bacterial agents that cause disease in ornamental fish have been identified so far, the number of reports of disease outbreaks seen in the freshwater angelfish is very limited.

Currently, very few fish pathogens have been identified as zoonotic. Species other than E. tarda within the genus Edwardsiella, classified in the Hafniaceae family, are predicted to have low zoonotic potential, either because they are highly species-specific in fish ( $E$. ictaluri - channel catfish) or have never been reported to cause infection in humans ( $E$. hoshinae). In contrast, $E$. tarda is likely to have a much higher zoonotic potential due to both its very wide geographic distribution and the wide variety of species it causes infection (Leung et al., 2012).

In humans, infections caused by Edwardsiellosis occur mostly in the form of gastroenteritis. Although it can be predicted that the gastrointestinal route will have a relatively low effect on zoonotic infections originating from ornamental fish, it has been reported that $E$. tarda also causes various infections other than this route such as soft tissue infections, septicaemia, meningitis, peritonitis, osteomyelitis, endocarditis and abscesses (Wang et al., 2005). However, information on the pathogenesis of E. tarda in mammals including humans, is very limited.

The aim of this study was to identify the causative agent responsible for an outbreak in the freshwater angelfish Pterophyllum scalare that occurred in an ornamental fish production facility.

Case history

\section{Materials and Methods}

The moribund freshwater angelfish (Pterophyllum scalare) individuals ( $n=4,20-25 \mathrm{~g}$ in weight) were sampled from a small-scaled ornamental fish production facility located in Istanbul to determine the cause of mortalities in the angelfish population. According to the data provided by the facility, the fish were fed two times per day with a commercial diet (name not given) and were kept under the following water parameters: temperature $28 \pm$ $2^{\circ} \mathrm{C}, \mathrm{pH} 7.5$ and water hardness $8^{\circ} \mathrm{dH}$, with a weekly $10 \%$ water changes and the mortality 
rate in the freshwater angelfish population within a week was $50 \%$ according to the information given.

Collection of samples and isolation of the causative agent

Internal organs, gills, body cavity and fins were examined for parasites using standard parasitological examination methods and then, bacteriological samples were taken from internal organs (liver, spleen, kidney tissues) and streaked onto Tryptic Soy Agar (TSA) (Merck) using aseptic techniques and the agar plates were incubated at $22^{\circ} \mathrm{C}$ for $48-72 \mathrm{~h}$. To get pure cultures, single colonies on the primary plates were selected and re-streaked onto the same media and incubated in same conditions (Whitman, 2004).

Characterization of the bacterial isolates

The morphological and physiological characteristics of the pure bacterial isolates were determined using conventional biochemical and physiological tests including colony and cell morphology, Gram staining, oxidase activity, catalase, motility, oxidation/fermentation $(\mathrm{O} / \mathrm{F})$ reaction, nitrate reduction, methyl red, Voges-Proskauer reaction, Triple Sugar Iron test, degradation of urea and citrate utilization (Whitman, 2004).

DNA extraction and $16 S$ rRNA gene amplification

The isolates on the agar plates were inoculated into Tryptic Soy Broth (TSB) (Merck) and incubated overnight at $22^{\circ} \mathrm{C}$, then total DNA was extracted using the PureLink Genomic DNA Mini Kit (Invitrogen, Carlsbad, CA, USA) according to the manufacturer's instructions. For the identification, a 540-bp-long fragment of the 16S rRNA gene was amplified and sequenced using the universal bacteria primer set: primer S-D-Bact-0008-a-S-20 and primer S-*-Univ-0536-a-A-18 (Suau et al., 1999).

The PCR mixture included approximately $50 \mathrm{ng}$ template DNA, $0.4 \mathrm{mM}$ of each primer, PCR Master Mix (2X) (Thermo Scientific) and nuclease- free water (Thermo Scientific). The amplification protocol was done using a thermal cycler (Biometra, TAdvanced) with the following parameters: initial denaturation at $95^{\circ} \mathrm{C}$ for $3 \mathrm{~min}$, followed by 30 cycles of amplification (denaturation at $95^{\circ} \mathrm{C}$ for $30 \mathrm{~s}$, annealing at $56^{\circ} \mathrm{C}$ for $1 \mathrm{~min}$, extension at $72^{\circ} \mathrm{C}$ for $1 \mathrm{~min}$ ) and a final extension step of $72^{\circ} \mathrm{C}$ for $4 \mathrm{~min}$. After amplification, PCR products were loaded on a $1.5 \%(\mathrm{w} / \mathrm{v})$ agarose gel in TAE containing ethidium bromide $(0.5 \mu \mathrm{g} / \mathrm{ml})$ and electrophoresis was performed (for $60 \mathrm{~min}$ at $90 \mathrm{~V}$ ). After visualizing and on a UV transilluminator and size estimation against GeneRuler 100 bp DNA Ladder (Thermo Scientific), PCR products were purified and sequenced in bidirectional. Sequence editing and analysis was performed in Bioedit v7.0.0 (Hall, 1999) using the ClustalX 2.1 (Larkin et al., 2007) and BLASTN 2.2.20 algorithm (Zhang et al., 2000). Similarity criterion in $16 \mathrm{~S}$ rRNA gene sequence was used as $\geq 99 \%$ for identification of the isolates at the species level (Clarridge, 2004). All sequences were deposited in GenBank database.

Antimicrobial susceptibility testing

All isolates were tested for antimicrobial susceptibility by the disc diffusion method on Mueller-Hinton agar using commercial disks (Oxoid). The antimicrobial agents tested were as follows: ampicillin, sulfamethoxazole with trimethoprim, tetracycline, flumequine, enrofloxacin and furazolidone. The test and interpretation of the results were carried out in accordance with the procedure by Clinical and Laboratory Standards Institute (CLSI) and the isolates were classified as sensitive or resistant on the basis of the diameters of zones of inhibition (CLSI, 2017).

Clinical findings

\section{Results}

The mortalities in the fish stock started immediately after the loss of appetite in fish without any other visible findings before, according to the information given from the production facility. As external findings in the examined fish, hemorrhage in the eyes and mild loss of scales and skin depigmentation were observed (Figure 1a, 1b, 1c, 1d). Internally; pale liver, enlarged and dark colored spleen were observed and the intestinal walls were thinned in the moribund fish (Figure 1c, 1d). 
a

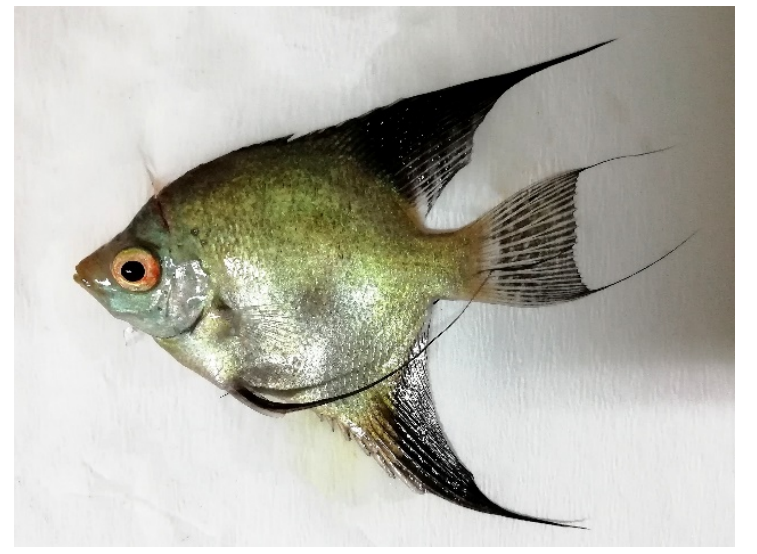

C

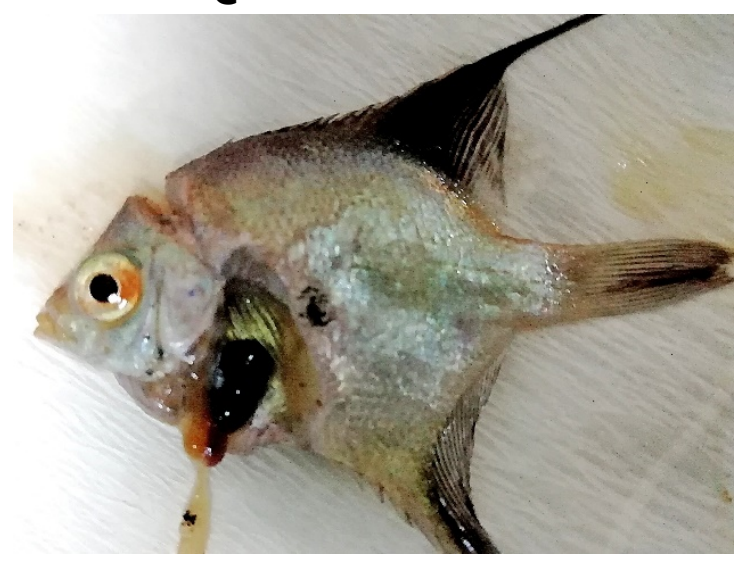

b

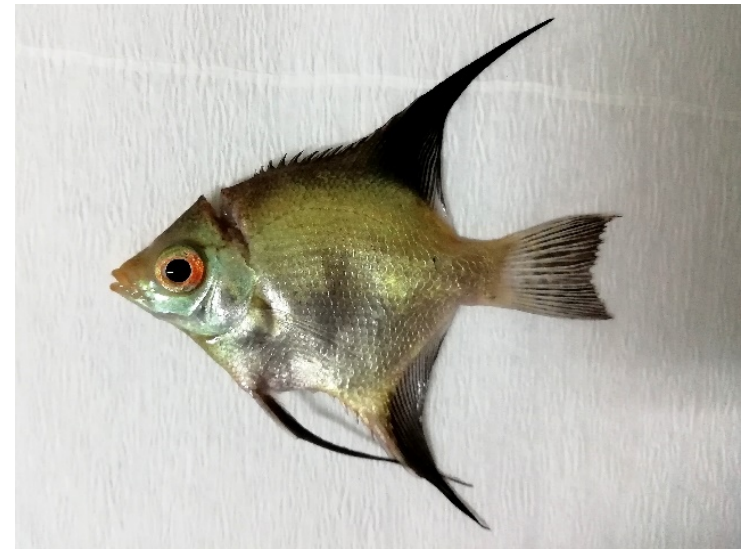

d

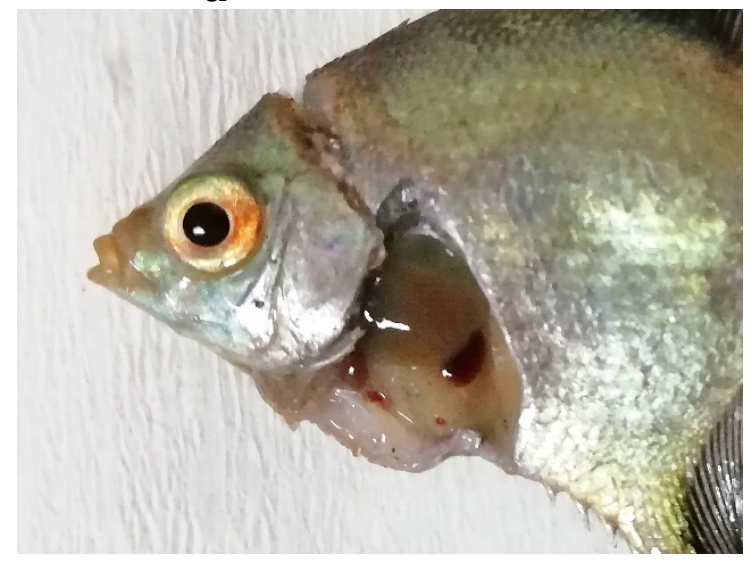

Figure $\mathbf{1}$ Clinical findings of the affected fish. Hemorrhage in the eyes $(\mathbf{a}, \mathbf{b}, \mathbf{c}, \mathbf{d})$ and loss of scales $(\mathbf{c}, \mathbf{d})$ and enlarged spleen $(\mathbf{c}, \mathbf{d})$ were common.

\section{Bacteriological findings}

The bacterial isolates were obtained from the kidney and the spleen tissues of diseased angelfish. All isolates were observed as Gram-negative, facultative anaerobic, motile rods and while cytochrome oxidase, methyl red, indole, nitrate reduction and catalase test were positive, Voges-Proskauer reaction, urea and citrate utilization were negative. Additionally, the isolates were arginine dihydrolase negative but lysine and ornithine decarboxylase positive and used only glucose among the carbohydrates tested (Table 1).

When the morphological and biochemical properties and 16S rRNA gene sequencing results were evaluated together, all isolated bacteria were identified as Edwardsiella tarda (GenBank accession numbers: MT860269- MT860272).

\section{Antimicrobial susceptibility test results}

According to the results of the disk diffusion test, it was determined that the isolates were sensitive to enrofloxacin, sulfamethoxazole with trimethoprim, furazolidone and flumequine, while being resistant to ampicillin and tetracycline antibiotics. 
Table 1 Morphological, phenotypic characteristics of the bacterial isolates

\begin{tabular}{|c|c|}
\hline Characteristics & Result \\
\hline Morphology & rods \\
\hline Motility & + \\
\hline Gram staining & - \\
\hline Catalase & + \\
\hline Cytochrome oxidase & - \\
\hline $\mathrm{O} / \mathrm{F}$ & $\mathrm{F}$ \\
\hline Indole & + \\
\hline Voges Proskauer reaction & - \\
\hline Methyl red & + \\
\hline Nitrate reduction & + \\
\hline Arginine dihydrolase & - \\
\hline Lysine decarboxylase & + \\
\hline Ornithine decarboxylase & + \\
\hline Gelatin & - \\
\hline Citrate & - \\
\hline Degradation of urea & - \\
\hline ONPG & - \\
\hline Tryptophan deaminase & - \\
\hline $\mathrm{H}_{2} \mathrm{~S}$ production & + \\
\hline \multicolumn{2}{|l|}{ Acid Production of } \\
\hline Glucose & + \\
\hline Mannose & - \\
\hline Arabinose & - \\
\hline Inositol & - \\
\hline Sorbitol & - \\
\hline Rhamnose & - \\
\hline Sucrose & - \\
\hline Melibiose & - \\
\hline Amygdalin & - \\
\hline
\end{tabular}

-: negative, +: positive, F: fermentative, O/F: Oxidative/Fermentative test

\section{Discussion}

Since it was first described by Meyer and Bullock (1973) in the channel catfish species, Edwardsiella tarda has been isolated from many commercially-produced fish species that appear to be both healthy and diseased (Austin and Austin, 2012; Park et al., 2012), from sediment (Acharya et al., 2007), from non-fish species including invertebrates, amphibians, reptiles, birds and from many mammalian groups including humans (Park et al., 2012).

Although Edwardsiellosis causes the most damage in the food-fish species such as channel catfish, tilapia, carp and olive flounder, it rarely causes disease outbreaks with heavy losses in ornamental fish (Lewbart, 2001). It is known that Edwardsiellosis may have very different pathogenesis in different fish species (Mohanty and Sahoo, 2007). Since the fish species in this study was different from those reported in the scientific literature and since the disease caused severe losses just a few days after the loss of appetite observed in fish; while some of the findings in this study coincided with the available data, many others were not observed in the diseased fish. In accordance with the reports of other researchers, the most obvious external finding in fish in this study was the loss of pigmentation on the skin of the fish (Kaige et al., 1986; Evans et al., 2011). However, ulcers (Nucci et al., 2002) or any odorous/odorless abscesses (Meyer and Bullock, 1973) were not observed on the skin, tail area or body surface. Consistent with some other reports, hemorrhage in the eyes (Padrós et al., 2006; Austin and Austin, 2012), the most reported finding of the infection, was common in all fish in this study as well. While 
pathological findings such as pale liver and enlarged spleen, which were also observed in other reports (Nucci et al., 2002; Padrós et al., 2006) were seen in this study; white nodules in visceral organs (Kaige et al., 1986) were not observed. In addition, abscess or bleeding in the muscles (Thune et al., 1993; Ling et al., 2001), also mentioned in many reports, were not seen in the diseased fish in our study.

The multi-antimicrobial resistance in the pathogenic Edwardsiella tarda strains has been well-documented so far (Sun et al., 2009). The strains obtained in this study were found to be resistant to ampicillin and tetracycline among the tested antibiotics, and this result is also compatible with other studies on $E$. tarda strains. In a previous study involving also the other species in the Edwardsiella genus (E. tarda, E. ictaluri, and E. hoshinae), all species were found to be naturally resistant to tetracycline (Stock and Wiedemann, 2001). In another study with diseased turbot fish, it was found that isolated $E$. tarda strains were intermediate resistant to ampicillin but resistant to tetracycline (Xiao et al., 2008). Sun et al. (2009) found tetracycline resistance in their strains isolated from an epidemic-inflicted fish farm in China. Yu et al. (2012) found tetracycline resistance in the strains isolated from diseased Japanese flounder, but different from our study, they reported that the strains they tested were susceptible to ampicillin.

Edwardsiellosis is often seen as an opportunistic infection, but it can cause bacteriological septicemias and losses in a wide variety of hosts, including both marine and freshwater fish species, invertebrates, amphibians, reptiles, birds and in many mammalian groups, including humans. Many bacterial pathogens isolated from diseased fish are also found in nature and even in the normal skin and intestine microbiota of fish (Austin and Austin, 2012). However, as with other animals, deviations beyond normal physiological limits make fish more susceptible to diseases, especially in captivity. The Edwardsiellosis caused by Edwardsiella tarda need for appropriate disease control and prevention measures. For this purpose, high water quality parameters, while ensuring proper stock density, and maintain proper hygiene and sanitation, keeping stress to minimum is important. In addition, as a finding observed in almost all isolates; this species has a general resistance to antibiotics that act against Gram-negative bacteria (Slaven et al., 2001). Therefore, the administration of chemotherapeutic agents needs to be done in a controlled manner for $E$. tarda, a zoonotic species that also causes disease in humans and is known to have multiple antibiotic resistance.

\section{References}

Acharya M., Maiti N.K., Mohanty S., Mishra P. and M. Samanta, 2007. Genotyping of Edwardsiella tarda isolated from freshwater fish culture system. Comp. Immunol. Microbiol. Infect. Dis., 30(1):33-40. https://doi.org/10.1016/j.cimid.2006.10.003

Austin B., D.A. Austin, 2012. Bacterial Fish Pathogens, Springer, Dordrecht, The Netherlands. 482 pp. https://doi.org/10.1007/978-3-319-32674-0

Clarridge J.E., 2004. Impact of 16S rRNA gene sequence analysis for identification of bacteria on clinical microbiology and infectious diseases. Clin. Microbiol. Rev., 17(4):840https://doi.org/10.1128/CMR.17.4.840-862.2004

CLSI - Clinical and Laboratory Standards Institute, 2017. Performance standards for antimicrobial susceptibility testing, $27^{\text {th }}$ Edition. CLSI supplement M100. ISSN: 2162-2914 Dey V.K., 2016. The global trade in ornamental fish. Infofish International, 4(16):23-29. Retrieved from http://infofish.org

Evans J.J., Klesius P.H., Plumb J.A. and C.A. Shoemaker, 2011. Edwardsiella septicaemias. Fish Diseases and Disorders. Volume 3: Viral, bacterial and fungal infections, (Ed. 2), 512-569. ISBN-13: 978-0851991948

Evers H.G., Pinnegar J.K. and M.I. Taylor, 2019. Where are they all from?-sources and sustainability in the ornamental freshwater fish trade. J. Fish Biol., 94(6):909-916. https://doi.org/10.1111/jfb.13930

Hall T.A., 1999. BioEdit: a user-friendly biological sequence alignment editor and analysis program for Windows 95/98/NT. In Nucleic Acids Symp. Ser. (Vol. 41, No. 41, pp. 95-98). [London]: Information Retrieval Ltd., c1979-c2000. 
Kaige N., Miyazaki T. and S.S. Kubota, 1986. A histopathological study of edwardsiellosis in tilapia-experimental infection. Fish Pathol., 21(2):95-99. https://doi.org/10.3147/jsfp.21.95

Kullander S.O., 2003. Family cichlidae. Check list of the freshwater fishes of South and Central America, 605-654. ISBN 85-7430-361-5

Ladisa C., Bruni M. and A. Lovatelli, 2017. Overview of ornamental species aquaculture. FAO Aquaculture Newsletter, (56), 39. Retrieved from http://www.fao.org/3/a-i7171e.pdf Larkin M.A., Blackshields G., Brown N.P., Chenna R., McGettigan P.A., McWilliam, H., ... and J.D. Thompson, 2007. Clustal $W$ and Clustal $X$ version 2.0. Bioinformatics, 23(21):2947-2948. https://doi.org/10.1093/bioinformatics/btm404

Leung K. Y., Siame B.A., Tenkink B.J., Noort R.J. and Y.K. Mok, 2012. Edwardsiella tarda-virulence mechanisms of an emerging gastroenteritis pathogen. Microbes Infect., 14(1): 26-34. https://doi.org/10.1016/j.micinf.2011.08.005

Lewbart G.A., 2001. Bacteria and ornamental fish. In Seminars in Avian and Exotic Pet Medicine (Vol. 10, No. 1, pp. 48-56). WB Saunders. https://doi.org/10.1053/saep.2001.19543

Ling S.H., Wang X.H., Lim T.M., K.Y. Leung, 2001. Green fluorescent protein-tagged Edwardsiella tarda reveals portal of entry in fish. FEMS Microbiol. Lett., 194(2):239-243. https://doi.org/10.1111/j.1574-6968.2001.tb09476.x

Meyer F.P. and G.L. Bullock, 1973. Edwardsiella tarda, a new pathogen of channel catfish (Ictalurus punctatus). Appl Microbiol, 25(1), 155. https://doi.org/10.1128/aem.25.1.155$\underline{156.1973}$

Mohanty B.R., P.K. Sahoo, 2007. Edwardsiellosis in fish: a brief review. J. Biosci., 32(3):1331-1344. https://doi.org/10.1007/s12038-007-0143-8

Noga E.J., 2010. Fish Disease: Diagnosis and Treatment. John Wiley \& Sons, Iowa. 536 pp. ISBN: 978-0-813-80697-6

Nucci C., Da Silveira W.D., da Silva Correa S., Nakazato G., Bando S.Y., Ribeiro M.A. and A.P. de Castro, 2002. Microbiological comparative study of isolates of Edwardsiella tarda isolated in different countries from fish and humans. Vet. Microbiol., 89(1): 29-39. https://doi.org/10.1016/S0378-1135(02)00151-7

Ortega H. and R.P. Vari, 1986. Annotated checklist of the freshwater fishes of Peru. Smithsonian Contributions to Zoology.

Padros F., Zarza C., Dopazo L., Cuadrado M. and S. Crespo, 2006. Pathology of Edwardsiella tarda infection in turbot, Scophthalmus maximus (L.). J. Fish Dis., 29(2):8794. https://doi.org/10.1111/j.1365-2761.2006.00685.x

Park S.B., Aoki T. and T.S. Jung, 2012. Pathogenesis of and strategies for preventing Edwardsiella tarda infection in fish. Vet. Res., 43(1), 67. https://doi.org/10.1186/12979716-43-67

Slaven E.M., Lopez F.A., Hart S.M. and C.V. Sanders, 2001. Myonecrosis caused by Edwardsiella tarda: a case report and case series of extraintestinal $E$. tarda infections. Clinical Infectious Diseases, 32(10): 1430-1433. https://doi.org/10.1086/320152

Suau A., Bonnet R., Sutren M., Godon J.J., Gibson G.R., Collins M.D. and J. Doré, 1999. Direct analysis of genes encoding 16S rRNA from complex communities reveals many novel molecular species within the human gut. Appl. Environ. Microbiol., 65(11):4799-4807. https://doi.org/10.1128/AEM.65.11.4799-4807.1999

Sun K., Wang H.L., Zhang M., Xiao Z.Z. and L. Sun, 2009. Genetic mechanisms of multi-antimicrobial resistance in a pathogenic Edwardsiella tarda strain. Aquaculture, 289(1-2):134-139. https://doi.org/10.1016/j.aquaculture.2008.12.021

Stock I. and B. Wiedemann, 2001. Natural Antibiotic Susceptibilities of Edwardsiella tarda, E. ictaluri, and E. hoshinae. Antimicrob. Agents Chemother., 45(8):2245-2255. https://doi.org/10.1128/AAC.45.8.2245-2255.2001

Thune R.L., Stanley L.A. and R.K. Cooper, 1993. Pathogenesis of gram-negative bacterial infections in warmwater fish. Annu. Rev. Fish Dis., 3:37-68. https://doi.org/10.1016/0959-8030(93)90028-A

Tlusty M., 2002. The benefits and risks of aquacultural production for the aquarium trade. Aquaculture, 205(3-4):203-219. https://doi.org/10.1016/S0044-8486(01)00683-4 
Wang I.K., Kuo H.L., Chen Y.M., Lin C.L., Chang H.Y., Chuang F.R. and M.H. Lee, 2005. Extraintestinal manifestations of Edwardsiella tarda infection. Int. J. Clin. Pract., 59(8): 917-921. https://doi.org/10.1111/j.1742-1241.2005.00527.x

Whitman K.A., 2004. Finfish and Shellfish Bacteriology Manual: Techniques and Procedures. Iowa state press. 258 pp ISBN: 978-0-813-81952-5

Xiao J., Wang Q., Liu Q., Wang X., Liu H. and Y. Zhang, 2008. Isolation and identification of fish pathogen Edwardsiella tarda from mariculture in China. Aquac. Res., 40(1):13-17. https://doi.org/10.1111/j.1365-2109.2008.02101.x

Yu J.E., Cho M.Y., Kim J.W. and H.Y. Kang, 2012. Large antibiotic-resistance plasmid of Edwardsiella tarda contributes to virulence in fish. Microb. Pathog., 52(5):259-266. https://doi.org/10.1016/j.micpath.2012.01.006

Zhang Z., Schwartz S., Wagner L. and W. Miller, 2000. A greedy algorithm for aligning DNA sequences. J. Comput. Biol., 7(1-2):203-214. https://doi.org/10.1089/10665270050081478 